九州大学学術情報リポジトリ

Kyushu University Institutional Repository

Subgeneric Positions and Redescriptions of Asian Andrena Preserved in the Zoological Institute, Russian Academy of Sciences, St. Petersburg (Hymenoptera, Andrenidae)

Xu, Huan- $\mathrm{l} i$

Entomological Laboratory, Faculty of Agriculture, Kyushu University

Tadauchi, Osamu

Entomological Laboratory, Faculty of Agriculture, Kyushu University

https://doi.org/10.5109/24142

出版情報 : 九州大学大学院農学研究院紀要. 41 (3/4)，pp. 165-178，1997-03. Kyushu University バージョン：

権利関係 : 


\title{
Subgeneric Positions and Redescriptions of Asian Andrena Preserved in the Zoological Institute, Russian Academy of Sciences, St. Petersburg (Hymenoptera, Andrenidae) ${ }^{1), 2), 3}$
}

\author{
Huan-li Xu and Osamu Tadauchi
}

Entomological Laboratory, Faculty of Agriculture, Kyushu University, Fukuoka 812-81, Japan

(Received October 31, 1996; Accepted December 17, 1996)

\begin{abstract}
Six species of the genus Andrena described from eastern and central Asia, which are preserved in the Zoological Institute, Russian Academy of Sciences, St. Petersburg, are redescribed and the following first 4 species are firstly given their subgeneric positions: Andrena (Andrena) scutellaris, A. (Andrena) genalis, A. (Oreomelissa) anthracina, A. (Lepidandrena) semiaenea, A. (Plastandrena) eversmanni and A. (Plastandrena) mongolica. Andrenawulungshanensis Yasumatsu is newly synonymized with $A$. orenburgensis Schmiedeknecht.
\end{abstract}

\section{INTRODUCTION}

Recently we have started studies on "Systematics, Evolution and Biogeography of Asian Andrena" and borrowed some types or paratypes from European and U. S. museums and institutes. Some of the species were simply described and not given their subgeneric positions by the former authors. It is necessary to give additional descriptions and their subgeneric positions. In this paper, we deal with seven species described by Morawitz (1876, 1880), Radoszkowski (1867), Schmiedeknecht (1883), from Mongolia, China, and central Asia which are preserved in the Zoological Institute, Russian Academy of Sciences, St. Petersburg. Andrena wulungshanensis Yasumatsu is newly synonymized with Andrena orenburgensis Schmiedeknecht. Abbreviations and style of descriptions follow Tadauchi and Xu (1995).

\section{Andrena (Andrena) scutellaris Morawitz}

(Figs. 1-4)

Andrena scutellaris Morawitz, 1880, Bull. Acad. Sci. St. Petersbourg, 26: 364 [female, Mongolia]; Yasumatsu, 1941, Peking nat. Hist. Bull., 15: 280 [in list].

Anthrena scutellaris: Dalla Torre, 1896, Cat. Hym., Apidae, 10: 151 [in list].

1) Contribution from the Entomological Laboratory, Faculty of Agriculture, Kyushu University, Fukuoka (Ser. 4, No. 114).

2) This work was supported by a Grant-in-Aid for Scientific Research of an International Scientific Research Program from the Ministry of Education, Science, Sports and Culture, Japan (No. 07041144) (Head Investigator: 0. Tadauchi).

3) Results from the China-Japan Co-operative Study on "Studies on Systematics, Evolution and Biogeography of Asian Andrena (Hym., Apoidea, Andrenidae)" No. 5. 
Redescription of the lectotype: Female: BL $12.0 \mathrm{~mm}$, WL $10.5 \mathrm{~mm}$.

Color: Flagellum reddish brown beneath; mandible with apical half and over reddened; wing membranes subhyaline, veins and pterostigma yellowish brown; tibial spurs yellowish; posterior depressions of metasomal terga yellowish brown.

Pubescence: Hairs on head dense, white; those on antennal area white mixed with brown; those on clypeus long $(750 \mu)$, dense; those on vertex more or less long (500750p), sparse, whitish mixed with brown; those on genal area brown near eye, whitish posteriorly; facial fovea brown. Hairs on thorax dense, whitish; those on mesoscutum rather long $(1000 \mu)$; propodeal corbicula well developed with complete anterior fringes, white, without internal hairs; mesepisternum with rather long $(1000 \mu)$ white hairs; trochanteral floccus perfect, white; femoral floccus dense; tibial scopa developed, composed of long, simple brown hairs. Hairs on metasomal terga whitish; those on $\mathrm{T}_{1.2}$ long; those on $\mathrm{T}_{3.4}$ mixed with short $(200-300 \mu)$, brown; those on $\mathrm{T}_{5}$ slightly long, dense, brown in the middle, white in the sides; caudal fimbria brown.

Structure: Head: $\mathrm{HL} / \mathrm{HW}=0.75$. HW $: \mathrm{MsW}: \mathrm{MtW}=4.0: 3.75: 4.0$. Vertex flat in frontal view, densely tessellate. OOD : POD : OCD $=0.9: 0.5: 0.25$. $\mathrm{FL}_{1}$ subequal to $\mathrm{FL}_{2}+$ ${ }_{3}$, FL, broader than long. Eyes with inner margins slightly converging toward mandible. Facial fovea long, exceeding the line between the lower margin of the antennal fossae, $\mathrm{FVL}=1.65 \mathrm{~mm}, \mathrm{FVW}=0.5 \mathrm{~mm}$. Clypeus slightly convex medially, finely tessellate, feebly shiny, surface with crowded PP $\phi 20-30 \mu$, IS $<0.5$, sparser medially, densely tessellate basally and laterally, CPL $=1.25 \mathrm{~mm}$. Process of labrum moderate, weakly emarginate apically. Lower paraocular area smooth and shiny with PP $\phi 10-20 \mu$, IS $<1$. Malar space broader than long, about $1 / 3$ as long as broad. Genal area broader than eye, GW : $\mathrm{EW}=1.0: 0.9$, surface weakly tessellate near eye, densely tessellate posteriorly with PP $\phi$ $10-20 \mu$, IS $=1$ or more. Mesosoma: Pronotum with distinct humeral angle, densely tessellate. Mesoscutum strongly tessellate peripherally, finely tessellate medially with weak indication of punctations. Scutellum finely tessellate anteriorly with PP $\phi 20 \mu$, IS < 1, irregular in distribution, densely tessellate posteriorly. Propodeal enclosure finely tessellate, feebly shiny, very weakly rugulose basally, dorsal face of propodeum roughened. Mesepisternum shagreened. Metasoma: Metasomal terga finely tessellate, weakly shiny, with weak indication of punctations; posterior depressions of terga broad, weakly indicated. Pygidial plate V-shaped with large raised triangular area.

Type material: Lectotype female was designated by Osychnyuk in 1980, No. 94657.

Remarks: The lectotype specimen is in bad condition, the right wing was destroyed. This species was described from Mongolia. Fortunately we found this species also distributed in Zhangye, Gansu Prov., China, in our specimens and it had the hairs on the body abundant, white and black, without brown hairs, mesoscutum and scutellum mixed with black hairs, the punctation is slightly stronger than that of lectotype. This species is similar to Andrena (Andrena) hondoica Hirashima from Japan, but it can be separated from hondoica by the larger size, the process of labrum emarginate apically and weakly rugulose at base of the propodeal enclosure.

Distribution: Mongolia; China (Gansu Prov.).

Floral record: China: Prunus sp. in a desert.

Flight record: Female: mid May. 


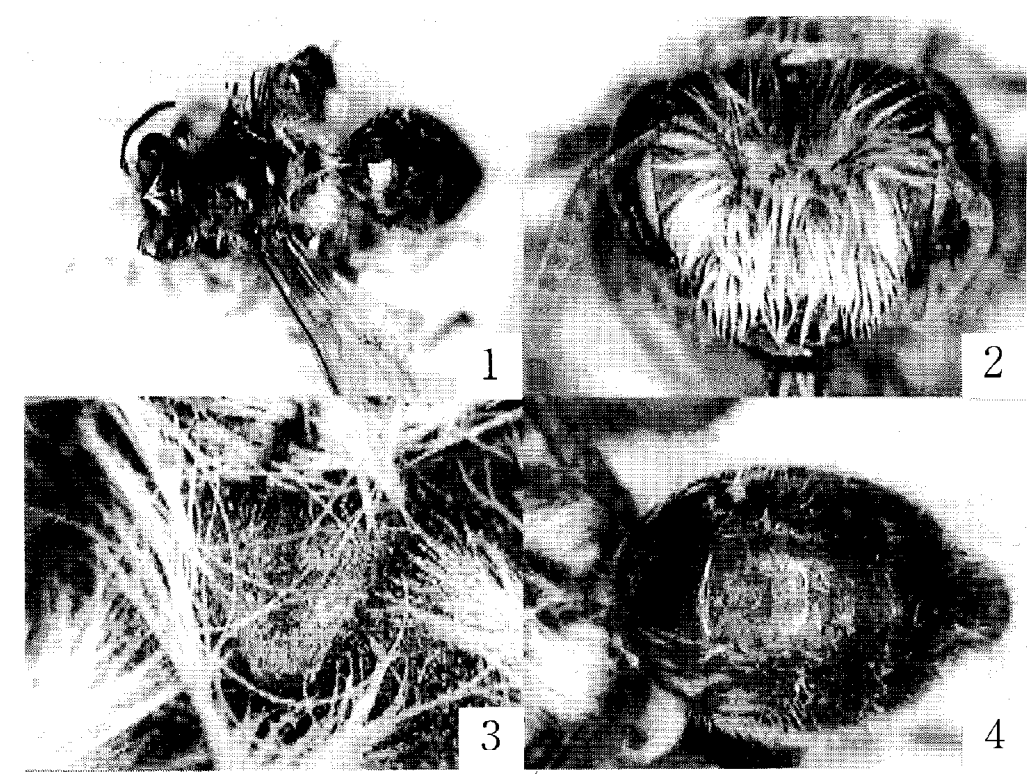

Figs. 1-4. Andrena (Andrena) scutellaris, 1: Dorsal view of the whole body; 2: Head in frontal view; 3: Propodeum; 4: Metasomal terga.
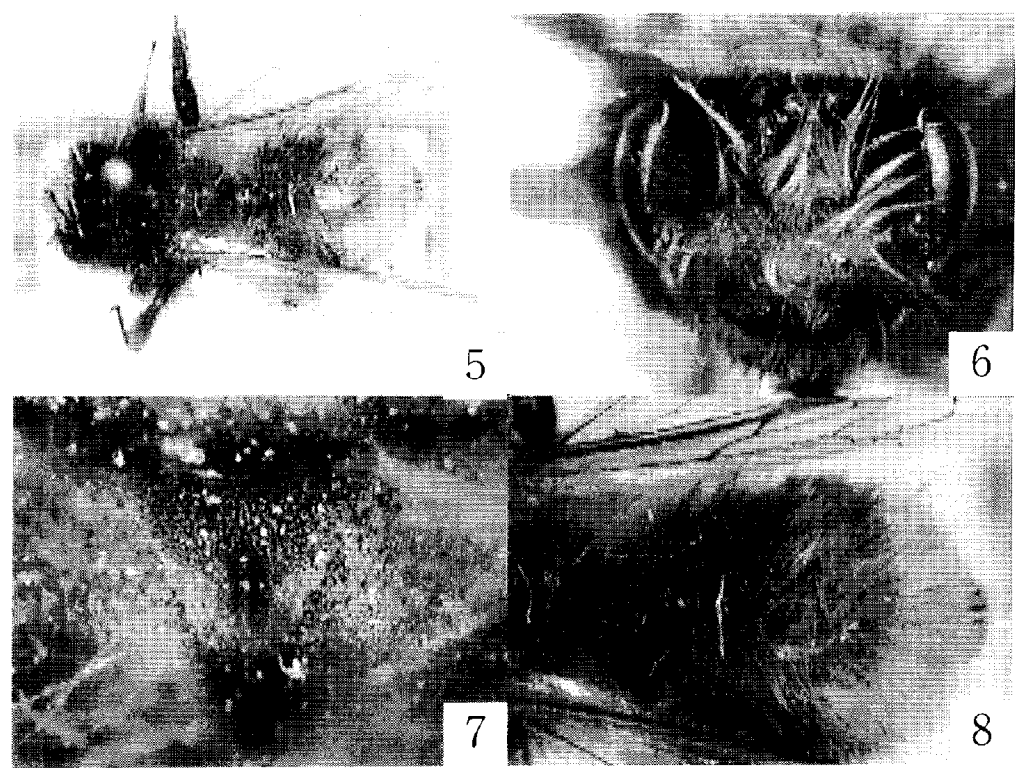

Figs. 5-8. Andrena (Andrena) genalis, 5: Dorsal view of the whole body; 6: Head in frontal view; 7: Propodeum; 8: Metasomal terga. 


\section{Andrena (Andrena) genalis Morawitz}

(Figs. 5-8)

Andrena genalis Morawitz, 1880, Bull. Acad. Sci. St. Petersbourg, 26: 360 [female, Mongolia]; Yasumatsu, 1941, Peking nat. Hist. Bull., 15: 276 [in list].

Anthrena genalis: Dalla Torre, 1896, Cat. Hym., Apidae. 10: 128 [in list].

Redescription of the lectotype: Female: BL $11.3 \mathrm{~mm}$, WL $9.0 \mathrm{~mm}$.

Color: Antenna lacking; mandible with apical half reddened; wing membranes subhyaline, slightly brownish, veins and pterostigma yellowish brown; tibial spurs ochraceous; posterior depressions of metasomal terga brownish.

Pubescence: Hairs on body abundant, long to rather long $(650-1500 \mu)$, those on antenna1 area yellowish; those on clypeus long $(650-1000 \mu)$, brown; those on vertex long, yellowish; those on genal area black; facial fovea dark brown. Hairs on mesoscutum rather long $(1000 \mu)$, mainly yellowish mixed with brownish medially and blackish laterally; those on scutellum and metanotum yellowish; propodeal corbicula well developed and complete with anterior fringes, pale yellowish above, brownish below, internal area almost without hairs; mesepisternum with rather long $(1000 \mu)$, black hairs; trochanteral floccus perfect, brown; femoral floccus dense; tibial scopa developed, composed of long, brown simple hairs. Hairs on metasomal terga rather dense and long $(1250 \mu)$, bright yellow and brownish laterally; caudal fimbria pale yellowish.

Structure: Head: $\mathrm{HL} / \mathrm{HW}=0.81 \mathrm{HW}: \mathrm{MsW}: \mathrm{MtW}=4.0: 3.9: 4.25$. Vertex weakly to finely tessellate. $\mathrm{OOD}: \mathrm{POD}: \mathrm{OCD}=0.95: 0.6: 0.25$. Eyes with inner margins subparalleled. Facial fovea broad, $\mathrm{FVL}=1.75 \mathrm{~mm}, \mathrm{FVW}=0.7 \mathrm{~mm}$. Clypeus slightly convex, finely tessellate with close PP $\phi 20 \mu, 1 \mathrm{X} 0.5$, with narrow median longitudinal impunctate space at apical half, not obvious, CPL $=1.25 \mathrm{~mm}$. Process of labrum large, deeply emarginate apically. Lower paraocular area as in clypeus. Malar space long, 1/2 as long as broad. Genal area broader than eye, $\mathrm{GW}: \mathrm{EW}=1.0: 0.8$, surface finely tessellate posteriorly, broadly, feebly shiny near eye with fine PP. Mesosoma: Pronotum with distinct humeral angle, densely tessellate with obscure PP. Mesoscutum shagreened peripherally, densely tessellate with shallow PP $\phi 20 \mu$, IS $=0.5-1$. Scutellum as in mesoscutum. Propodeal enclosure small, slightly excavated medially, densely tessellate; dorsal face of propodeum densely tessellate, not roughened. Mesepisternum shagreened. Metasoma: Metasomal terga weakly tessellate with sparse PP; posterior depressions of terga narrow, not well indicated. Pygidial plate V-shaped with large raised triangular area. $S_{2-4}$ densely tessellate, apical half with obscure PP.

Type material: Lectotype female was designated by Osychnyuk in 1980, No. 94165.

Remarks: This species superficially resembles Andrena armata (Gmelin) of Europe in having abundant, long colored hairs on the body. But it can be separated from armata by the smaller size, the densely punctate clypeus, and the deeply emarginate process of labrum [broad, median longitudinal impunctate space on the clypeus and entire process of labrum in armata].

Distribution: Mongolia.

Floral record: Not available.

Flight record: Not available. 


\section{Andrena (Oreomelissa) anthracina Morawitz}

(Figs. 9-16)

Andrena anthracina Morawitz, 1880, Bull. Acad. Sci. St. Petersbourg, 26: 359 [female \& male, China]; Yasumatsu, 1941, Peking nat. Hist. Bull., 15: 273 [in list].

Anthrena anthracina: Dalla Torre, 1896, Cat. Hym., Apidae, 10: 103 [in list].

Redescription of the paralectotype: Female: BL $8.7 \mathrm{~mm}$, WL $6.6 \mathrm{~mm}$.

Color: Flagellum brownish beneath; mandible with apical third reddened; wing membranes subhyaline, veins and pterostigma reddish brown; tibial spurs ochraceous; posterior depressions of metasomal terga reddish brown.

Pubescence: Hairs on head brownish; those on clypeus short $(250-400 \mu)$; those on vertex slightly longer $(500-550 \mu)$; facial fovea dark brownish. Hairs on thorax sparse, except mesepisternum with long $(600-850 \mu)$, dense, brownish; those on mesoscutum and scutellum $(400-700 \mu)$, brownish mixed with whitish; propodeal corbicula brownish, sparse, poorly developed, with internal hairs short, sparse; trochanteral floccus imperfect, whitish; femoral floccus not so dense; tibial scopa composed of long, dense, simple hairs, whitish in front, brownish posteriorly. Hairs on $\mathrm{T}$, scanty; those on $\mathrm{T}_{2.4}(350-500 \mu)$ whitish, suberect laterally; caudal fimbria brownish; $\mathrm{S}_{2-5}$ with well arranged subapical fimbriae .

Structure: Head: HL/HW $=0.90$. HW $: \mathrm{MsW}: \mathrm{MtW}=2.5: 2.5: 2.5$. Vertex well developed, arched in frontal view, densely tessellate. OOD : POD : OCD $=0.6: 0.4: 0.25$. $\mathrm{FL}_{1}>\mathrm{FL}_{213}, \mathrm{FL}_{2}=\mathrm{FL}_{3}, \mathrm{FL}$, nearly as long as broad. Eyes with inner margins subparalleled. Facial fovea deep, narrowing toward below, $\mathrm{FVL}=1 . \mathrm{O} \mathrm{mm}, \mathrm{FVW}=0.35 \mathrm{~mm}$. Clypeus slightly convex, densely tessellate basally and laterally, weakly tessellate apicomedially, feebly shiny with crowded PP $\phi 20-40 \mu$, IS $<0.5$, sparser medially, CPL $=0.8 \mathrm{~mm}$. Process of labrum moderate, convex and weakly emarginate apically. Lower paraocular area smooth and shiny with close PP. Malar space nearly linear. Genal area broader than eye, $\mathrm{GW}: \mathrm{EW}=0.8: 0.6$, surface finely tessellate posteriorly, smooth and shiny with fine PP near eye. Mesosoma: Pronotum weakly tessellate with obscure PP. Mesoscutum densely tessellate anteriorly and posteriorly, weakly tessellate medially with fine, shallow PP $\phi 15 \mu$, IS $=1-2$. Scutellum nearly shagreened. Propodeum densely tessellate all over, not roughened, enclosure large, weakly roughened at basal margin. Mesepisternum shagreened. Metasoma: $\mathrm{T}_{1}$ smooth and shiny with microscopic PP, irregular in distribution; $\mathrm{T}_{2-4}$ weakly tessellate, shiny with weak microscopic PP, irregular in distribution; posterior depressions of metasomal terga broad, not well indicated. Pygidial plate U-shaped, with small raised triangular area. $\mathrm{S}_{2-5}$ finely tessellate, impunctate basally, finely punctate apically.

Redescription of the lectotype: Male: BL $7.0 \mathrm{~mm}$, WL $6.2 \mathrm{~mm}$.

Color: Flagellum reddish brown beneath; clypeus ivory white except near base of mandible; lower paraocular area with linear ivory white marking apically; mandible with apical third reddened; wing membranes subhyaline, moderately brownish, veins and pterostigma reddish brown; tibial spurs yellowish; posterior depressions of metasomal terga reddish brown.

Pubescence: Hairs on head, brownish except clypeus, antennal area and lower part of 


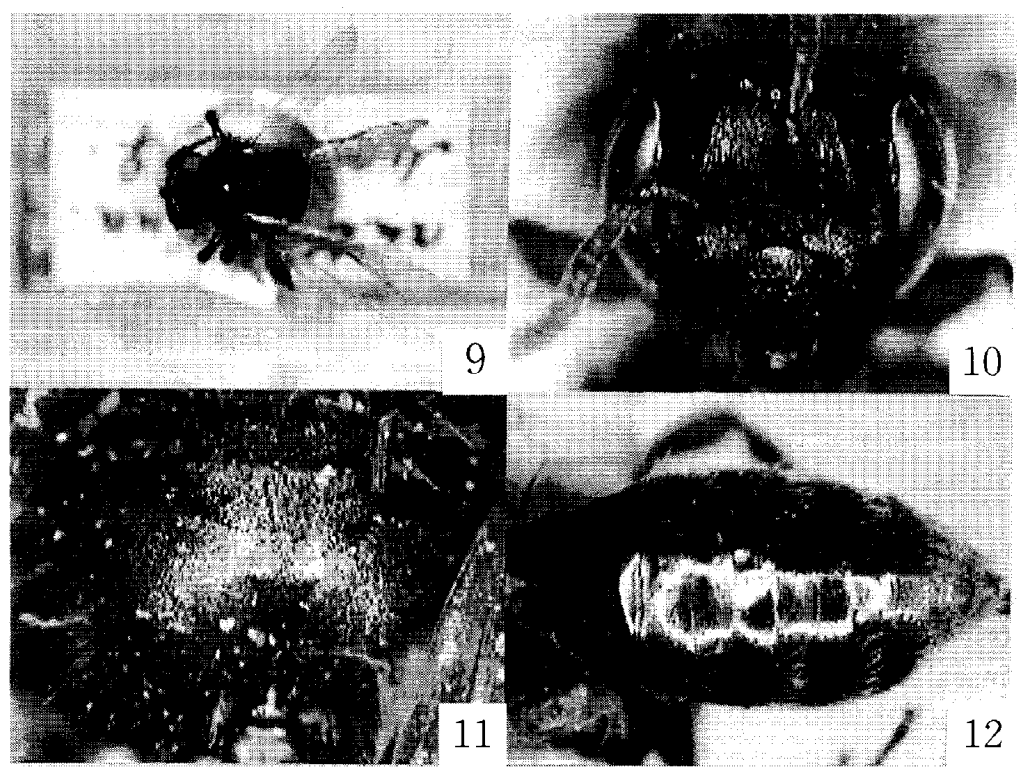

Figs. 9-12. Andrena (Oreomelissa) anthracina, female, 9: Dorsal view of the whole body; 10 Head in frontal view; 11: Propodeum; 12: Metasomal terga.

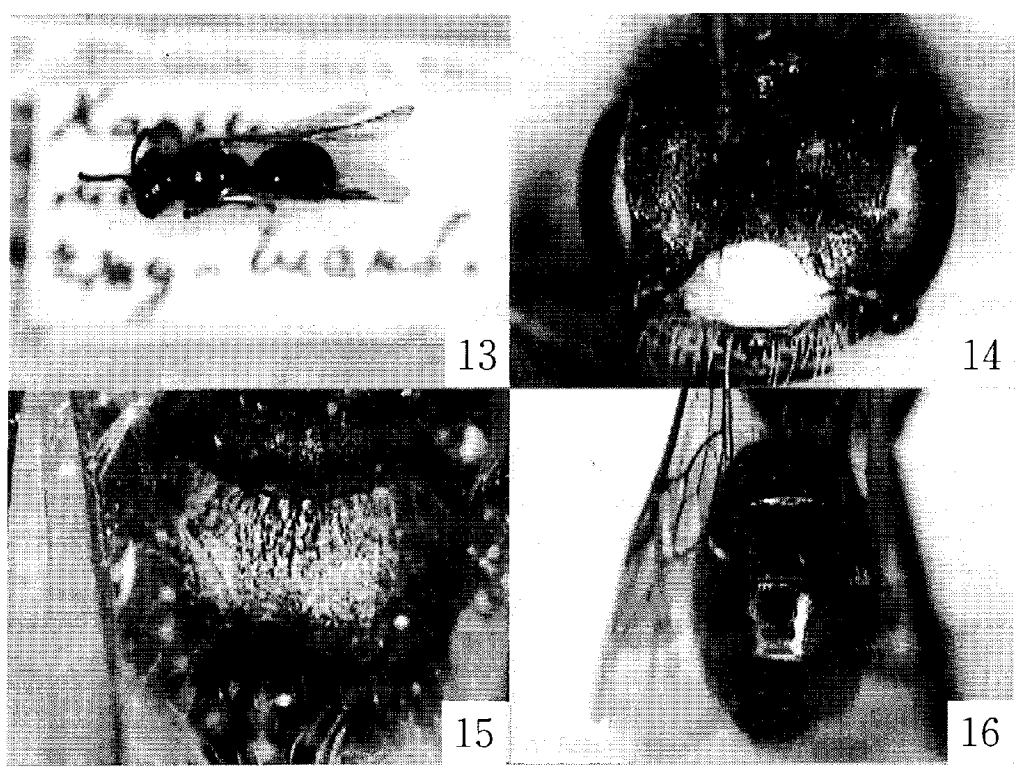

Figs. 13-16. Andrena (Oreomelissa) anthracina, male, 13: Dorsal view of the whole body; 14: Head in frontal view; 15: Propodeum; 16: Metasomal terga. 
genal area mixed with whitish; those on clypeus short $(250-400 \mu)$; those on vertex short $(250-350 \mu)$. Hairs on thorax moderately long $(500-600 \mu)$, those on mesoscutum brownish mixed with whitish anteriorly and laterally; those on scutellum and metanotum brownish; those on mesepisternum long, whitish. Hairs on metasomal terga short $(100-300 \mu), \mathrm{T}_{1.2}$ sparse erect, white; $\mathrm{T}_{2.4}$ dense, brown; $\mathrm{T}_{1-3}$ with lateral whitish hairs apically.

Structure: Head: HL/HW $=0.84$. HW $: \mathrm{MsW}: \mathrm{MtW}=2.25: 2.2: 2.05$. Vertex well developed, distinctly arched in frontal view, weakly tessellate, shiny. OOD : POD : OCD = $0.5: 0.25: 0.25$. $\mathrm{FL}_{1}=\mathrm{FL}_{2+3}, \mathrm{FL}_{2}=\mathrm{FL}_{3}$. Eyes with inner margins subparalleled. Clypeus slightly convex, smooth and shiny, sparsely and weakly punctate, $\mathrm{CPL}=0.5 \mathrm{~mm}$. Process of labrum convex, deeply emarginate apically. Lower paraocular area smooth and shiny with PP $\phi 20 \mu$, IS $<1$. Malar space nearly linear. Genal area slightly broader than eye, $\mathrm{GW}: \mathrm{EW}=0.65: 0.56$, weakly tessellate, shiny with fine $\mathrm{PP} \phi 10 \mu, \mathrm{IS}=1$. Mesosoma: Pronotum densely tessellate. Mesoscutum densely tessellate anteriorly and posteriorly, weakly tessellate medially, shiny with fine PP $\phi 15 \mu$, IS $=1-2$. Scutellum convex, weakly tessellate, shiny with PP $\phi 15 \mu$, IS $=1$. Propodeal enclosure large, weakly rugulose basally, densely tessellate apically; dorsal face of propodeum densely tessellate, not roughened. Mesepisternum densely tessellate with weak PP. Metasoma: Metasomal terga smooth to weakly tessellate, shiny; $\mathrm{T}_{1}$ with PP $\phi 15 \mu, \mathrm{IS}=1-3 ; \mathrm{T}_{2-4}$ with PP $\phi 15 \mu$, IS = 1 basally, sparser apically; posterior depressions of metasomal terga not well indicated.

Type material: Paralectotype female was designated by A. Osychnyuk in 1980, No. 77773. Lectotype male was designated by A. Osychnyuk in 1980.

Remarks: This species is similar to Andrena coitana (Kirby) from Europe. The female of anthracia can be separated from that of coitana by the clypeus and the metasomal terga less tessellate, shiny; the facial fovea not broadly separated from the orbit of eye; the scutellum and the matasomal terga less punctate. The male of anthracia can be separated from that of coitana by the process of labrum deeply emarginate apically, the mesoscutum with sparser and smaller PP, and the fore wing with basal vein broadly distad of nervulus.

Distribution: China (Gansu Prov.).

Floral record: Not available.

Flight record: Not available.

\section{Andrena (Lepidandrena) semiaenea Morawitz}

(Figs. 17-20)

Andrena semiaenea Morawitz, 1876, Puteshestvie Turkestan Mellifera ii. 213 [female, Russia; Mongolia]; Yasumatsu, 1941, Peking nat. Hist. Bull., 15: 280 [in list]. Anthrena semiaenea, Dalla Torre, 1896, Cat. Hym., Apidae, 10: 151 [in list].

Redescription of the paralectotype: female: BL $8.7 \mathrm{~mm}$, WL $5.3 \mathrm{~mm}$.

Color: Flagellum reddish yellow beneath; mandible with apical half reddened; wing membranes subhyaline, veins and pterostigma yellowish brown; tibial spurs yellowish brown; $\mathrm{T}_{1-3}$ with broad red markings; posterior depressions of metasomal terga yellowish, 
transparent.

Pubescence: Hairs on head and thorax short, whitish; those on clypeus scanty, short $(150-250 \mu)$; those on vertex rather sparse, short $(150-250 \mu)$; those on genal area dense, white; facial fovea black above, whitish below. Hairs on mesoscutum and scutellum rather short, dense, velvety, dull whitish; those on mesepisternum short $(200-$ $400 \mu$ ), whitish; propodeal corbicula poorly developed, with dull whitish hairs not well arranged, with interior hairs sparse, simple; trochanteral floccus nearly perfect, white; femoral floccus dense; tibial scopa moderately developed, composed of dense, simple whitish hairs. Hairs on metasomal terga rather short, whitish; $\mathrm{T}_{1-4}$ with white hair bands $(200 \mu)$; caudal fimbria yellowish.

Structure: Head: $\mathrm{HL} / \mathrm{HW}=0.83$. $\mathrm{HW}: \mathrm{MsW}: \mathrm{MtW}=2.4: 2.5: 2.5$. Vertex rounded in frontal view, weakly tessellate. OOD : POD : $\mathrm{OCD}=0.45: 0.4: 0.2$ FL $_{1}=\mathrm{FL}_{2+3}$. Eyes with inner margins subparalleled. Facial fovea narrow, $\mathrm{FVL}=1.1 \mathrm{~mm}, \mathrm{FVW}=0.2 \mathrm{~mm}$. Clypeus convex, smooth and shiny with shallow PP $\phi 10-20 \mu$, IS $=\mathbf{1}-2$, irregular in distribution, $\mathrm{CPL}=0.75 \mathrm{~mm}$. Process of labrum moderate, rounded apically. Lower paraocular area as in clypeus. Malar space linear. Genal area as broad as eye, GW : EW $=0.65: 0.65$, smooth and shiny with obscure PP. Mesosoma: Pronotum without humeral angle, densely tessellate. Mesoscutum weakly tessellate with PP $\phi 10 \mu$, IS $<0.5$, shiny. Scutellum shagreened by crowded PP. Propodeal enclosure densely tessellate to weakly rugose; dorsal face of propodeum shagreened. Mesepisternum densely tessellate with shallow, sparse PP. Metasoma: Metasomal terga smooth and shiny with fine close PP $\phi 10 \mu$, IS $<1$; posterior depressions of terga narrow, not well indicated. Pygidial plate V-shaped, with raised internal triangular area.

Type material: Paralectotype female was designated by Osychnyuk in 1980.

Remarks: This species is similar to Andrena chengtehensis Yasumatsu from China in having velvety hairs on the mesoscutum, scutellum and metasomal terga. However, the female of semiaenea can be separated from that of chengtehensis by the smaller size, whitish hairs on the body and the process of labrum rounded at apex.

Distribution: Turkestan; Mongolia.

Floral record: Not available.

Flight record: Not available.

\section{Andrena (Plastandrena) eversmanni Radoszkowski}

(Figs. 21-24)

Andrena eversmanni Radoszkowski, 1868, Horae Soc. ent. Ross., 74 [female \& male, Central Asia]; Schmiedeknecht, 1883, Apid. Europ. I. 434 [female], 475 [male]; Morawitz, 1890, Horae.Soc. ent. Ross., 24: 357 [Mongolia]; Yasumatsu, 1941, Peking nat. Hist. Bull., 15: 280 [in list]; Popov, 1958, Horae Soc. ent. Union. Sovet., 46:131 [female in key], 140 [male in key].

Anthrena eversmanni, Dalla Torre, 1896, Cat. Hym., Apidae, 10: 120 [in list].

Redescription of the type: female: BL $10.5 \mathrm{~mm}$, WL $7.6 \mathrm{~mm}$.

Color: Flagellum reddish brown beneath; mandible reddened apically; wing 
membranes slightly infumate, veins and pterostigma reddish brown; tibial spurs yellowish; posterior depressions of metasomal terga reddish yellow.

Pubescence: Hairs on head and thorax dense, whitish; those on clypeus short (300$400 \mu$ ); those on vertex short $(250 \mu)$; those on genal area more abundant; facial fovea whitish. Hairs on mesoscutum short $(400-750 \mu)$, scanty in the middle; those on scutellum nearly scanty, except short, whitish hairs posteriorly; those on mesepisternum slightly long $(650-750 \mu)$; propodeal corbicula complete, well arranged whitish hairs $(750-1000 \mu)$ with internal hairs sparse, simple; trochanteral floccus perfect, whitish; femoral floccus long, dense; tibial scopa well developed, composed of long, simple whitish hairs. $\mathrm{T}$, free of hairs medially, short $(250-350 \mu)$, sparse white hairs laterally; $\mathrm{T}_{2-4}$ with complete whitish dense hair bands; caudal fimbria whitish; $S_{2-5}$ with white subapical fimbriae.

Structure: Head: $\mathrm{HL} / \mathrm{HW}=0.73 . \mathrm{HW}: \mathrm{MsW}: \mathrm{MtW}=3.25: 3.2: 3.25$. Vertex flat. OOD : POD : $\mathrm{OCD}=0.5: 0.5: 0.15 . \mathrm{FL}_{1}=\mathrm{FL}_{2+3}$. Eyes with inner margins slightly diverging toward base of mandible. $\mathrm{FVL}=1.75 \mathrm{~mm}, \mathrm{FVW}=0.35 \mathrm{~mm}$. Clypeus slightly convex, crowded PP $\phi 20 \mu, \mathrm{IS}<0.1, \mathrm{CPL}=1.0 \mathrm{~mm}$. Process of labrum small, about $1 / 3$ as long as broad, transverse. Lower paraocular area with close PP as in clypeus. Genal area narrower than eye, GW : $\mathrm{EW}=0.60: 0.75$, weakly tessellate with fine, close PP. Mesosoma: Pronotum weakly tessellate with large PP. Mesoscutum and scutellum weakly tessellate, shiny with dense PP $\phi 20 \mu$, IS $<1$. Propodeal enclosure small, not well defined, concave medially, strongly rugosed to weakly wrinkled with carina apically; dorsal face of propodeum strongly roughened. Mesepisternum rugoso-punctate with large, dense PP. Posterior spur of hind tibia strongly bent and abruptly widened near base. Metasoma: Metasomal terga weakly tessellate, shiny; T, with PP $\phi 20 \mu$, IS $<1 ; \mathrm{T}_{2-4}$ with PP $\phi 10 \mu$, IS $<$ 0.5 ; posterior depressions of terga not well indicated. Pygidial plate tongue-shaped with raised internal triangular area. $\mathrm{S}_{2.5}$ weakly tessellate, shiny with crowded PP as in terga.

Redescription of the paratype: Male: BL $9.2 \mathrm{~mm}$, WL $7.1 \mathrm{~mm}$.

Color: Flagellum reddish brown beneath; mandible with apical third reddened; wing membranes subhyaline, brownish, veins and pterostigma reddish brown; tibial spurs yellowish; $\mathrm{T}_{1-2}$ ferruginous; posterior depressions of metasomal terga reddish brown.

Pubescence: Hairs on head and thorax whitish, more or less dense except clypeus, posterior mesoscutum and scutellum scanty; those on clypeus short $(350 \mu)$; those on vertex short $(350-500 \mu)$; those on genal area dense; those on mesoscutum short $(300-$ $500 \mu)$; those on metasomal terga short $(100-350 \mu)$, suberect to erect; $\mathrm{T}_{2-5}$ with complete white hair bands.

Structure: Head: $\mathrm{HL} / \mathrm{HW}=0.78$. HW $: \mathrm{MsW}: \mathrm{MtW}=3.0: 2.75: 2.9$. Vertex slightly rounded. OOD : POD : $\mathrm{OCD}=0.5: 0.5: 0.15 . \mathrm{FL}_{1}<\mathrm{FL}_{2+3}, \mathrm{FL}_{1}=\mathrm{FL}_{2}$. Eyes with inner margins subparalleled. Clypeus slightly convex, shiny with close PP $\phi 20 \mu$, IS $<1$, $\mathrm{CPL}=0.9 \mathrm{~mm}$. Process of labrum small, slightly emarginate apically. Lower paraocular area as in clypeus. Malar space linear. Genal area narrower than eye, GW : EW $=0.5$ : 0.75 , weakly tessellate with close PP. Mesosoma: Mesoscutum smooth and shiny with PP $\phi 20 \mu$, IS $<0.5$. Scutellum smooth and shiny with PP $\phi 40 \mu$, IS $<1$. Propodeal enclosure strongly wrinkled, not well defined; dorsal face of propodeum strongly rugose. Metasoma: Metasomal terga weakly tessellate, shiny with fine, close PP; $\mathrm{T}_{1}$ with PP $\phi 10 \mu, \mathrm{IS}=1 ; \mathrm{T}_{2-5}$ with closer PP, IS $<1$; posterior depressions of terga broad, well indicated. 

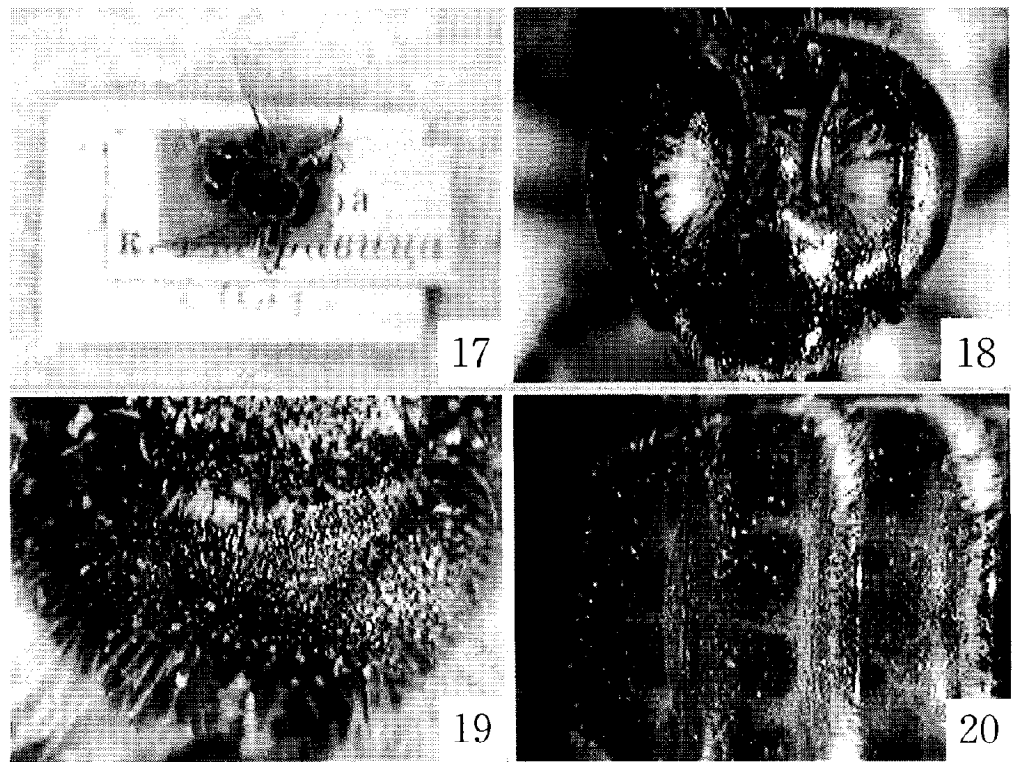

Figs. 17-20. Andrena (Lepidandrena) seminenea, 17: Dorsal view of the whole body; 18: Head in frontal view; 19: Propodeum; 20: Metasomal terga.
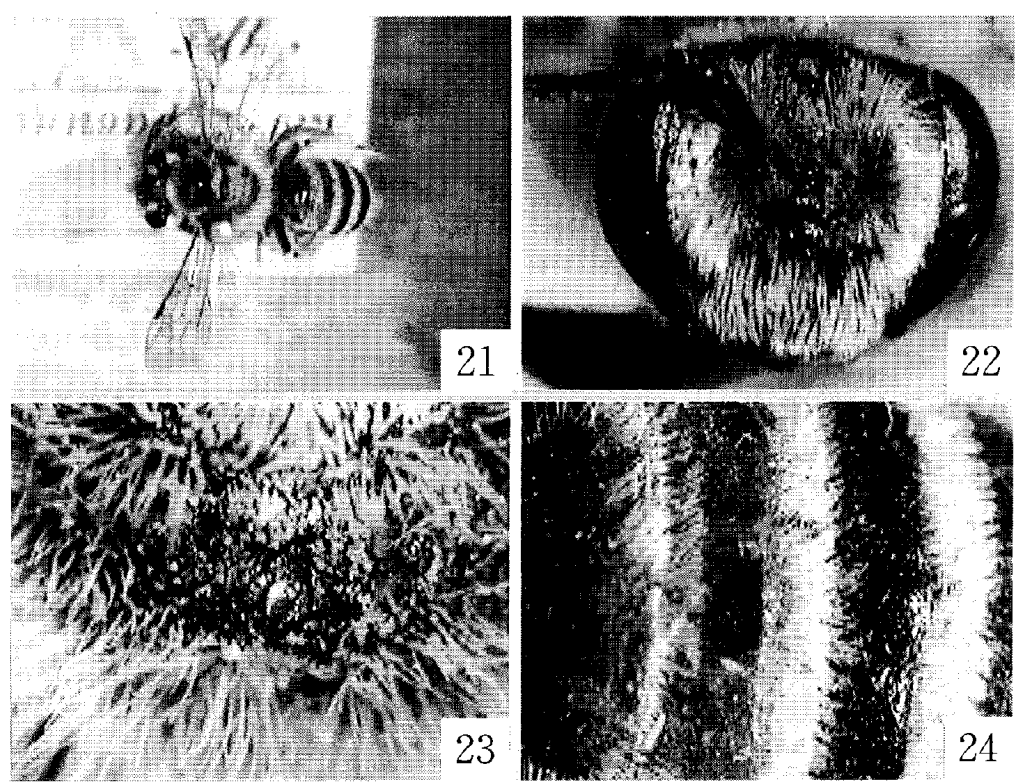

Figs. 21-24. Andrena (Plastandrena) eversmanni, 21: Dorsal view of the whole body; 22: Head in frontal view; 23: Propodeum; 24: Metasomal terga. 
Type material: Holotype female. Paratype male no. 81550.

Remarks: This species is separated from the other members of Plastandrena by hairs on the body abundant, white, the facial fovea white, the mesoscutum and scutellum with subvelvety hairs and the metasomal terga with broad, decumbent hair bands in female. The male is similar to the female except the male characteristics.

Distribution: Kazakestan; Turkestan; Mongolia; China (Gansu Prov.).

Floral record: China: Salix sp.

Flight records: China: Female and male: early May.

\section{Andrena (Plastandrena) mongolica Morawitz}

(Figs. 25-28)

Andrenamongolica Morawitz, 1880, Bull. Acad. Sci. St. Petersbourg, 26: 360 [female,

Mongolia]; Yasumatsu, 1941, Peking nat. Hist. Bull., 15: 278 [in list]; Popov, 1949, Ent.

Obozr., 30: 393 [female \& male, Russia]; Popov, 1958, Horae Soc. ent. Union. Sovet., 46: 133 [female, in key], 141 [male, in key].

Anthrena mongolica: Dalla Torre, 1896, Cat. Hym., Apidae. 10: 151 [in list].

Andrena (Plastandrena) apiformis mongolica: Warncke, 1967, Eos, 43: 289.

Redescription of the lectotype: Female: BL $13.2 \mathrm{~mm}$, WL $11.5 \mathrm{~mm}$.

Color: Flagellum reddened beneath; mandible reddened apically; wing membranes subhyaline, moderately brown, veins and pterostigma reddish yellow; tibial spurs ochraceous; $\mathrm{T}_{1-3}$ with reddish yellow markings laterally; posterior depressions of metasomal terga yellowish.

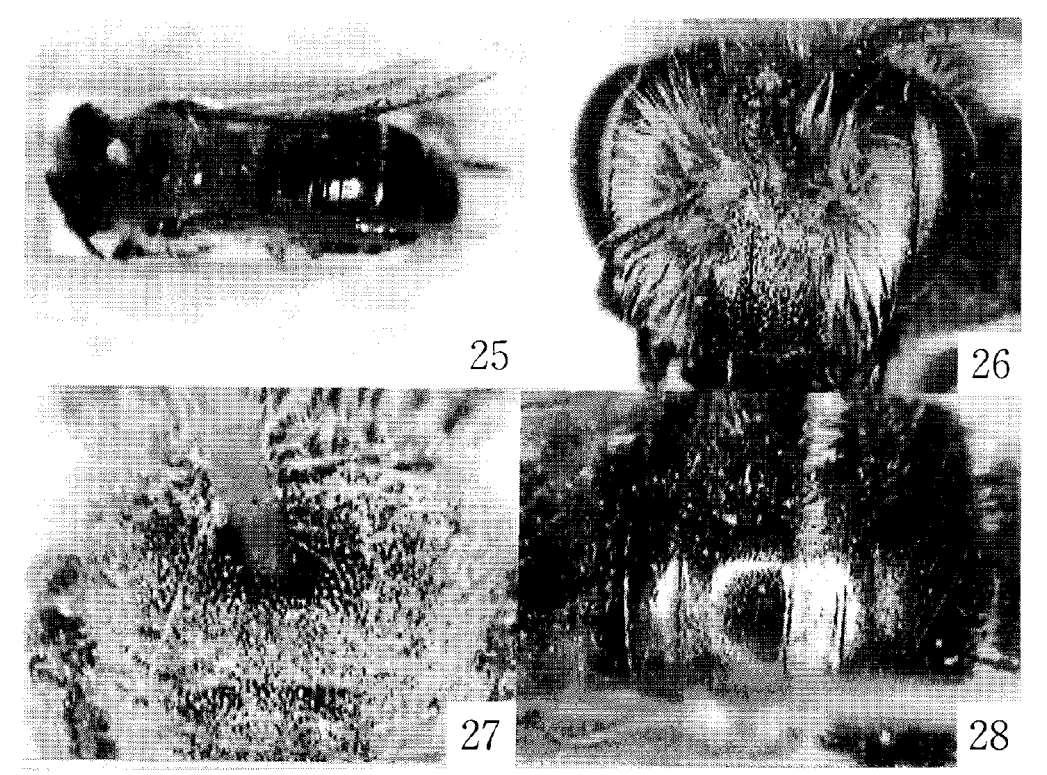

Figs. 25-28. Andrena (Plastandrena) mongolica, 25: Dorsal view of the whole body; 26: Head in frontal view; 27: Mesosoma; 28: Metasomal terga. 
Pubescence: Hairs on head dense, whitish to pale brownish; those on clypeus sparse in the lectotype; those on antennal area long, dense; those on vertex moderately long $(500-750 \mu)$, pale brownish; facial fovea brownish above, whitish below. Hairs on mesoscutum and scutellum moderately long $(500-750 \mu)$, dull whitish; those on mesepisternum long $(750-1000 \mu)$, dull whitish; propodeal corbicula developed, with well arranged dull whitish hairs, interior with sparse, simple hairs; trochanteral floccus perfect, whitish; femoral floccus dense; tibial scopa well developed, composed of long, simple whitish hairs. Hairs on metasomal terga short; $\mathrm{T}_{1-2}$ with long $(750 \mu)$, erect, dull whitish; $\mathrm{T}_{3-4}$ with short $(\mathrm{ZOO}-350 \mu)$, sparse hairs; $\mathrm{T}_{2 \cdot 4}$ with dull white hair bands apically, caudal fimbria bright brown,.

Structure: Head: $\mathrm{HL} / \mathrm{HW}=0.76$. $\mathrm{HW}: \mathrm{MsW}: \mathrm{MtW}=4.2: 4.3: 4.5$. Vertex shagreened. OOD : POD : $\mathrm{OCD}=0.8: 0.6: 0.3 . \mathrm{FL}_{1}<\mathrm{FL}_{2+3}, \mathrm{FL}_{2}<\mathrm{FL}_{3}, \mathrm{FL}_{2}$ as long as broad. Eyes with inner margins subparalleled. Facial fovea long, narrowing toward below, FVL $=2.0 \mathrm{~mm}$, $\mathrm{FVW}=0.6 \mathrm{~mm}$. Clypeus well convex, reticulo-punctate with $\mathrm{PP} \phi 20-40 \mu, \mathrm{IS}<0.5$, with median longitudinal carina above; $\mathrm{CPL}=1.5 \mathrm{~mm}$. Process of labrum short, about 1/3 as long as broad, nearly rounded apically. Lower paraocular area shiny, with dense PP $\phi$ $30 \mu$, IS $<0.5$. Malar space more or less short, $1 / 3$ as long as broad. Genal area slightly broader than eye, GW : EW = 1.0:0.9, feebly shiny and shagreened with weak PP. Mesosoma: Mesoscutum weakly tessellate with large PP $\phi 60 \mu$, IS $<1$ in the middle, densely tessellate peripherally. Scutellum weakly tessellate with large PP posteriorly. Propodeal enclosure coarsely wrinkled with keel apically, dorsal face of propodeum shagreened. Mesepisternum strongly roughened with rough PP. Posterior spurs of hind tibia strongly bent and abruptly widened near base. Metasoma: Metasomal terga smooth to weakly tessellate, shiny ; $\mathrm{T}_{1-2}$ with PP $\phi 10 \mu$, IS $=1-2 ; \mathrm{T}_{3-4}$ with PP $\phi 10 \mu$, IS $=1$; posterior depressions of terga broad, well indicated. Pygidial plate large, V-shaped, with large raised triangular area. $\mathrm{S}_{2.5}$ densely tessellate, $\mathrm{PP}$ as in terga.

Type material: Lectotype female was designated by A. Osychnyuk in 1980, No. 95107.

Remarks: The type specimen was recorded from Mongolia, and it has also collected in Russia and China. In our specimens from China, the female with abundant yellow hairs on the clypeus, thorax and metasomal terga. This species is similar to Andrena cypricola Mavromoutakis from Europe. But it can be easily separated from cypricola by the longer $\mathrm{FL}_{3}$, the coarsely punctate clypeus, the longer malar space and hair bands on the metasomal terga. Warncke (1967) treated this species as a subspecies of Andrena apiformis Kriechbaumer of Europe. But we could not examine A. apiformis. We treat A. mongolica as a species in this paper and will study it in future.

Distribution: Russia; Mongolia; China (Gansu Prov.).

Floral record: China: Prunus.sp. in a desert.

Flight record: Female: China: mid May.

\section{Andrena (Melandrena) orenburgensis Schmiedeknecht}

Andrena orenburgensis Schmiedeknecht, 1883, Apid. Europ. I. 458 [female, Russia], 494 [male]; Morawitz, 1890, Horae Soc. ent. Ross., 24: 357 [in list]; Yasumatsu, 1941, Peking nat. Hist. Bull., 15: 280 [in list]. 
Anthrena orenburgensis: Dalla Torre, 1896, Cat. Hym., Apidae, 10: 151 [in list]. Andrena compta Eversmann, 1852, Bull. Soc. nat. Moscou, 25: 12. [nec Lepeletier].

Andrena (Glyphandrena) wulungshanensis Yasumatsu, 1935, Insect of Jehol, 8: 2, 36 [female, China]; Okabe, 1939, Trans. Kansai Ent. Soc., (8): 12 [in list]; Yasumatsu, 1941, Peking nat. Hist. Bull., 15: 282 [in list]; Yasumatsu, 1947, Mushi: 18: 32 [in list]. New synonym

Andrena (Gymnandrena) wulungshanensis: Hirashima, 1957, Mushi, 30 (10): 65 [male, Japan]; Hirashima, 1964, J. Fac. Agr., Kyushu Univ., 13: 57 [redescription, female \& male, Japan]; Hirashima, 1966, J. Fac. Agr., Kyushu Univ., 14: 107 [female in key], 118 [male in key].

Type material: Paralectotype female of Andrena compta was designated by Osychnyuk in 1980.

Remarks: This species was firstly described as Andrena compta by Eversmann (1852), which was homonymized with A. compta Lepeletier (1841), and was given a new name Andrena orenburgensis by Schmiedeknecht in 1884. A. (Gymnandrena) wulungshanensis Yasumatsu is newly synonymized with $A$. orenburgensis. This species is similar to A. (Melandrena) albopunctata (Rossi) according to Osychnyuk (1977), but we did not examine albopunctata in the present study. In Asia, this species is remarkable species and easily separated from others of Melandrena by the larger size, pale white hairs on the head and thorax, and broad and lateral white hair bands on the metasomal terga.

Distribution: East Europe; Mongolia; China; Japan.

Floral record: China: Brassica campestris.

Flight records: Female and male: mid August to September.

\section{ACKNOWLEDGEMENT}

We are grateful to Dr. Y. Pesenko of the Zoological Institute, Russian Academy of Sciences, St. Petersburg for sending useful material on loan.

\section{REFERENCES}

Dalla Torre, C. G. de 1896 Catalogus Hymenopterorum vol. 10, Apidae. 643pp

Hirashima, Y. 1957 Descriptions and records of bees of the genus Andrena from eastern Asia IV (Hymenoptera, Andrenidae). Mushi, 30: 59-66

Hirashima, Y. 1964 Systematic and biological studies of the family Andrenidae of Japan (Hymenoptera, Apoidea) Part 2. Systematics, 3. J. Fac. Agr., Kyushu Univ., 13: 39-69

Hirashima, Y. 1966 Systematic and biological studies of the family Andrenidae of Japan (Hymenoptera, Apoidea) Part 2. Systematics, 7. J.Fac. Agr., Kyushu Univ., 14: 89-131

Morawitz, F. 1876 Part 13, Section 2, Zoogeographicheskia Izledovania, Division 5. Pcheli (Mellifera), fasc. 2. In "Puteshestvie v Turkestan [Travels in Trukestan]", ed. by A. Fedchenko, St. Petersburg \& Moscow, pp. 161-304

Morawitz, F. 1880 Ein Beitrag zur Bienen-Fauna Mittel-Asiens. Bull. Acad. Sci. St. Petersbourg, 26: 333389

Morawitz, F. 1890 Insecta a Cl. G. N. Potanin in China et in Mongolia novissime lecta. XIV. Hymenoptera Aculeata. III . Apidae. Horae Soc. ent. Ross., 24: 349-385 
Popov, B. B. 1949 Subgenus Plastandrena Hedicke and its new representatives (Hymenoptera, Apoidea). Ent. Obozr., 30: 389-404

Popov, B. B. 1958 On three subgenera of the genus Andrena (Hymenoptera, Andrenidae). Horae Soc. ent. Union. Sovet., 46: 109-161

Radoszkowski, 0. 1876 Materiaux pour servirá une faune hyméoptèrologique de la Russie. Horae Soc. ent. Ross., 12: 82-86

Tadauchi, 0. and H.-I. Xu 1995 A revision of the subgenus Simandrena of the genus Andrena of eastern Asia with a key to Palaearctic species (Hymenoptera, Andrenidae). Esakia, (35): 201-222

Warncke, K. 1967 Beitrag zur klarung paläarktischer Andrena-Arten (Hym. Apidae). Eos, 43: 171-381

Yasumatsu, K. 1935 Report of the First Scientific Expedition to Manchoukuo. Insects of Jehol, fasc. 8, Apoidea. 47pp

Yasumatsu, K. 1941 A list of the Far Eastern species of the genus Andrena (Hym., Apoidea). Peking nat. Hist. Bull., 15: 273-284

Yasumatsu, K. 1947 Some of wasps and bees of the desert Kunshan-Tagh in Inner Mongolia. Mushi, 18: $29-33$ 